\title{
A COMPARATIVE STUDY ON PLANTING CUCUMBER HYBRIDS BY USING CUTTINGS AND CONVENTIONAL METHOD
}

\author{
AYOUB, FAHEMA H. AND O.A.H. EL-ZEINY
}

Vegetables Research Dep., Horticultural Res.Instit. ARC,Dokki,Giza

(Manuscript received 28 February 2011)

\begin{abstract}
The experiment was carried out during the two successive seasons of 2008/2009 and 2009/2010 on cucumber plants (Cucumis sativus L.) Hesham hybrid, grown under greenhouse condition. Two types of cuttings, i.e., terminal and basal, were taken from pruning the side shoots of cucumber hybrid to encourage the development of cuttings instead of the expensive seeds of the hybrids. The results indicated that terminal cuttings were superior to the basal cuttings for obtaining the highest values of survival percentage, root length, fresh and dry weight of the produced seedlings.

To have a full understanding about the vegetative growth habits of cutting culture and their total yield in comparison to those of conventional plants (seed sowing), both types of seedlings produced from cuttings (terminal and basal) and seed propagation were planted at the same time in a greenhouse.

The results summarized that conventional plant method produced plants characterized with longest shoots and more leaf chlorophyll content, bigger leaf area, greater fresh and dry weight of plant and at the same time produced higher early and total yield than those derived from cutting propagation.

Economical comparison study was done to evaluate the cost price of seedlings and total yield obtained by cutting propagation and those obtained by conventional plants, the differences were calculated in terms of money according to the price of the market. Cutting techniques led to a reduction in the cost price of hybrid seedling production and increased the total income. It can be said that the asexual propagation by terminal cuttings is more economic and may be considered the best way to stop the increasing costs of hybrid seeds year after year and a best present procedure to replace the traditional nursery methods.
\end{abstract}

\section{INTRODUCTION}

Cucumber (Cucumis sativus L.) is one of the most important vegetable crops in Egypt. Cucumber plants are cultivated under greenhouse using hybrid seeds to obtain high productivity, but the seeds are very expensive. Due to the continuous increasing in price of hybrid seeds year after year, the asexual propagation by cutting method may be become of great benefit (El- Abd, 1997). 
Using chemical growth regulators to promote rooting when using asexual propagation technique is widely spread especially the auxins which are the most important chemicals used to enhance rooting (Seeley 1990).

Treating different plant cuttings by dipping in IBA at 500 or $1000 \mathrm{ppm}$ (according to cuttings age and type) for a few seconds promote adventitious root formation, i.e., root number and root length (Robinson et. al., 1993). It is of interest to note that auxin induce ethylene $\left(\mathrm{C}_{2} \mathrm{H}_{4}\right)$ production (Mullins, 1972) .As well as through inducing cell division that led to xylem differentiation cambial activity, root differentiation and hence root formation (Battern \& Goodwin, 1978 ; Seeley, 1990).

El-Abd (1997) reported that treating the cuttings of hybrid cucumber ( Katia) with IBA at 1000 ppm was effective in increasing the number, length and fresh weight of adventitious roots of cucumber cutting as compared with control cuttings (untreated).

The age of plant parts that used for cutting propagation has a considerable effect on root formation. Cutting taken from younger plant part usually gave more rapid rooting than those from older ones, however, age factor probably has its effect through its influence on the nutritive content of cutting (Hess, 1981).

The information at hand about the economical studies does not allow routine cutting propagation from all plants. Nevertheless, sufficient data have been accumulated and guidelines can be offered, so that detailed steps for specific crops can be developed with a minimum of research.

The aim of this work was to throw light on using different cutting types of cucumber hybrid (Hesham) which were taken from pruning of cucumber plants grown in the green house conditions. It is well known that the pruning and remove its residues is one of the main agricultural practices in producing cucumber under greenhouse condition. Also, to choose the best type of cuttings which produce best vegetative growth, and total yield to reduce the cost price of seeds as well as total profit of cucumber hybrid plants.

\section{MATERIALS AND METHODS}

This work was carried out in an unheated plastic house $6 \times 45 \mathrm{~m}$ and $3.5 \mathrm{~m}$ height at Kaha Research Farm during the two successive seasons of 2008/2009 and $2009 / 2010$.

Cucumber seeds (Cucumis sativus L) of Hesham hybrid were sown on August 20 and 23 for the first and second seasons, respectively. Cucumber seedlings with three true leaves (15 days old) were transplanted inside the plastic house. After 
25 days from transplanting, cuttings with $20 \mathrm{~cm}$ length taken from pruned side shoots (terminal and basal) and dipped 15 second in Indole Butyric Acid (IBA) at 1000 ppm solution according to the method of EL- Abd (1997). Cuttings from both parts were planted in pots filled with a mixture of peat moss and vermiculate at a ratio of $1: 1$ ( $\mathrm{v}$ : v) enriched with some essential nutrients. All pots were kept for 21 days in green house and the following data were recoded.

1- Percentage of stand.

2- Root length.

3- Fresh and dry weight of seedlings.

To have a full understand about the vegetative growth habits of cutting culture and their total yield in comparison to those of conventional plants (seed sowing), both the seedlings produced by cuttings (terminal and basal) and by seed propagation were planted at the same time inside plastic house $9 \times 60 \mathrm{~m}$ and $3.5 \mathrm{~m}$ height at Kaha Research Farm on September 26 and 29 of 2008 and 2009 seasons, respectivelly. The treatments were arranged randomly in 3 replicates using a randomized complete design. The seedlings were planted on ridges $1 \mathrm{~m}$ wide, spacing of $50 \mathrm{~cm}$ between rows and $50 \mathrm{~cm}$ between plants. Each replicate consisted of 20 plants. The plastic house was equipped with drip irrigation system.Other agriculture practices were done according to the recommendations of planting cucumber under greenhouse condition.

\section{Data recorded}

\section{A: Vegetative growth}

Plant length was determined after 45 and 90 days from planting, root length, total leaf chlorophyll content in the $4^{\text {th }}-5^{\text {th }}$ leaf from plant top using chlorophyll meter (SPAD unit), leaf area of the $4^{\text {th }}-5^{\text {th }}$ leaf from plant top using leaf area meter (LI-300-COR - Lincolin) and fresh and dry weight of plant. All of them were recorded at 90 days from planting.

\section{B: Yield and fruit characters}

Early yield, measured as weight of cucumber fruits during the first two weeks of harvesting period, total yield was recorded as total weights of all pickings, yield component measured as average fruit weight and the total number of fruits produced form all pickings. 


\section{Statistical analysis}

Data were subjected to proper statistical analysis of variance procedure and means were compared using the L.S.D. method at $5 \%$ level of significance according to Snedicor and Cochran (1980).

\section{C: Economical evaluation}

Comparative study was done to evaluate the value of total yield obtained by cutting culture method and traditional method, the difference was calculated in terms of Egyptian money according to the price of the market during the harvesting period.

\section{RESULTS AND DISCUSSION}

Dipping the two types of cuttings (terminal and basal) in IBA solution at concentration of $1000 \mathrm{ppm}$ resulted in significant effect on survival percentage, rooting formation, seedlings dry and fresh weight as shown in Fig. (1). data cleared that terminal cuttings were better than the basal cuttings in values of both the survival percentage and root formation expressed as root number and length. Our results are in agreement with results of Ali (1980). The information variability for terminal and basal cuttings may be related to the content of the endogenous hormones which was higher in terminal cuttings compared with the basal cuttings. Furthermore, terminal cuttings have actually higher meristemic activity than that of the basal cuttings. In this respect the formation of new organs such as root primordia would be much easier in terminal cuttings (Ikram, 1983). 

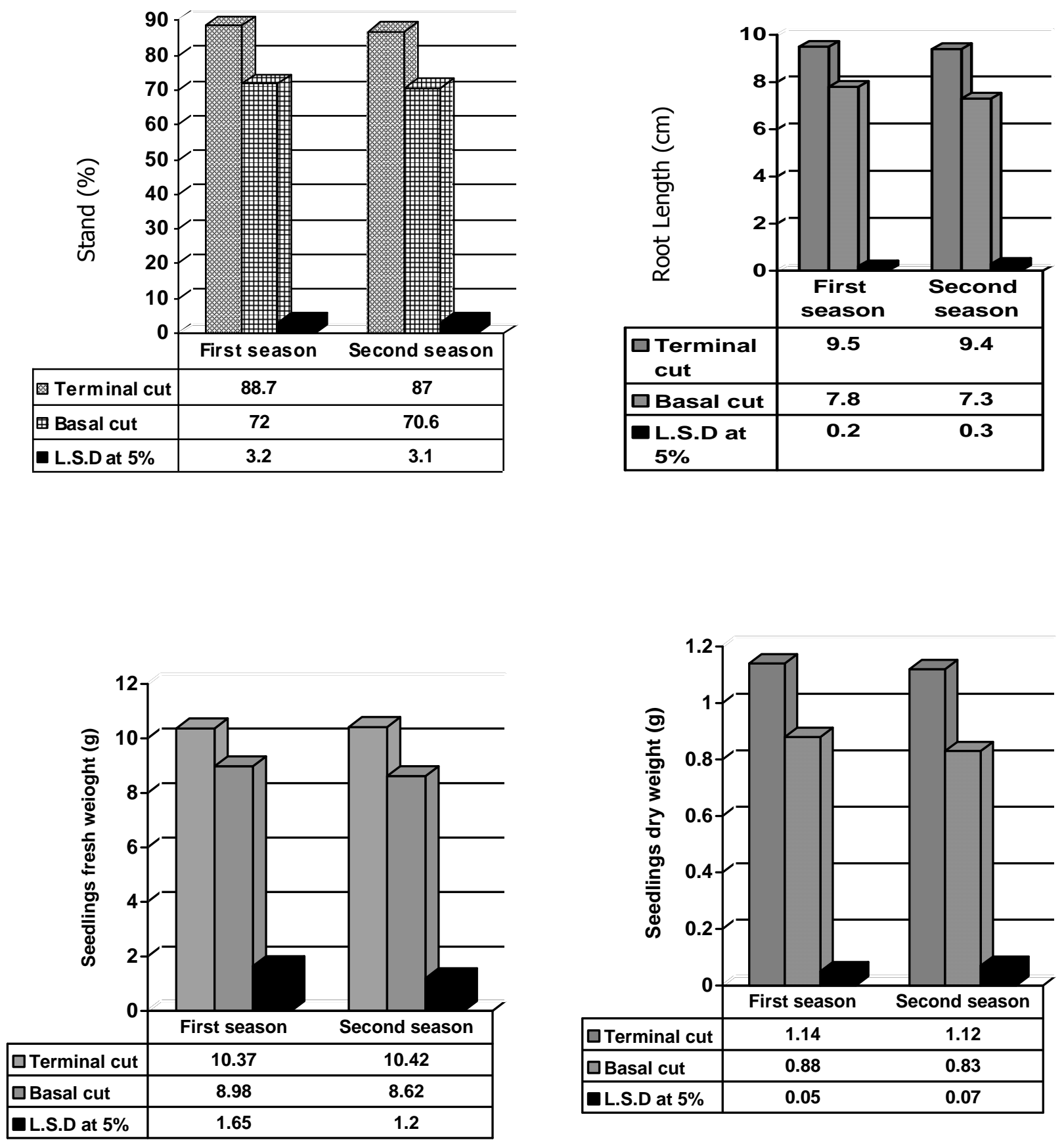

Fig. 1. Comparison between terminal and basal cutting on stand percentage, root length, fresh and dry weight of seedlings. 


\section{A-Vegetative growth}

Data presented in Figs $(2,3,4$ and 5) showed clearly that the traditional propagation method (seed sowing) produced plants characterized by vigorous vegetative growth expressed as plant height, total chlorophyll, leaf area, plant fresh and dry weight with good root formation compared with those propagated with cuttings (terminal or basal) in the two seasons under investigation. The superiority of traditional plant propagation suggested that the promotional effect of such young age (juvenile) plant part on root formation via its relatively proper nutritive and hormonal status compared with those of cuttings plants.

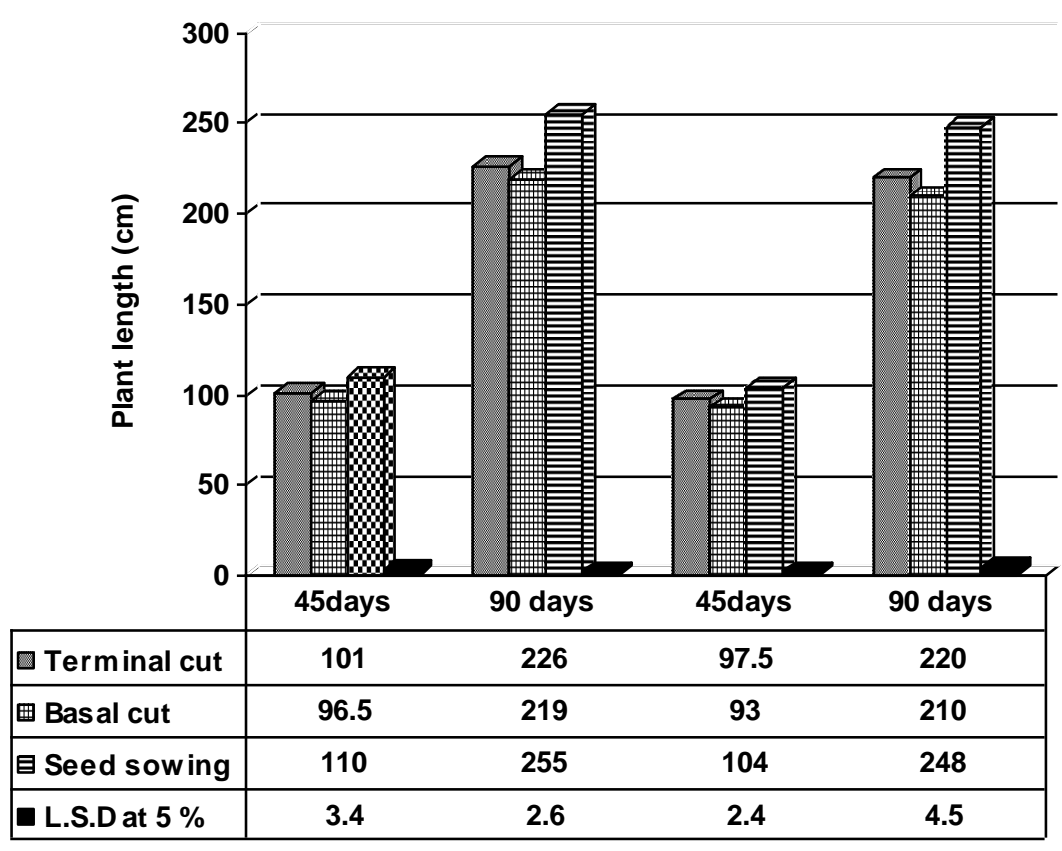

\section{First season}

Second season

Fig. 2. Comparison between seed sowing and cutting culture on plant length.

Hess (1981) indicated that younger plant part usually have roots more readily than those from older one, however, age factor probably has its effect through its influence on the nutritive content of plant as well as the endogenous content of auxin. Auxins known to induce cell division that lead to root differentiation and formation. On the other side, the vigorous root formation in plants obtained from seed sowing propagation creates favorable conditions for nutrient uptake and metabolite translocation, which ultimately accelerate the rate of vegetative growth (Battern \& Good win, 1978, Seeley, 1990). Meanwhile, data also show that terminal cutting plant propagation was best than the basal cutting in the previous characters. 

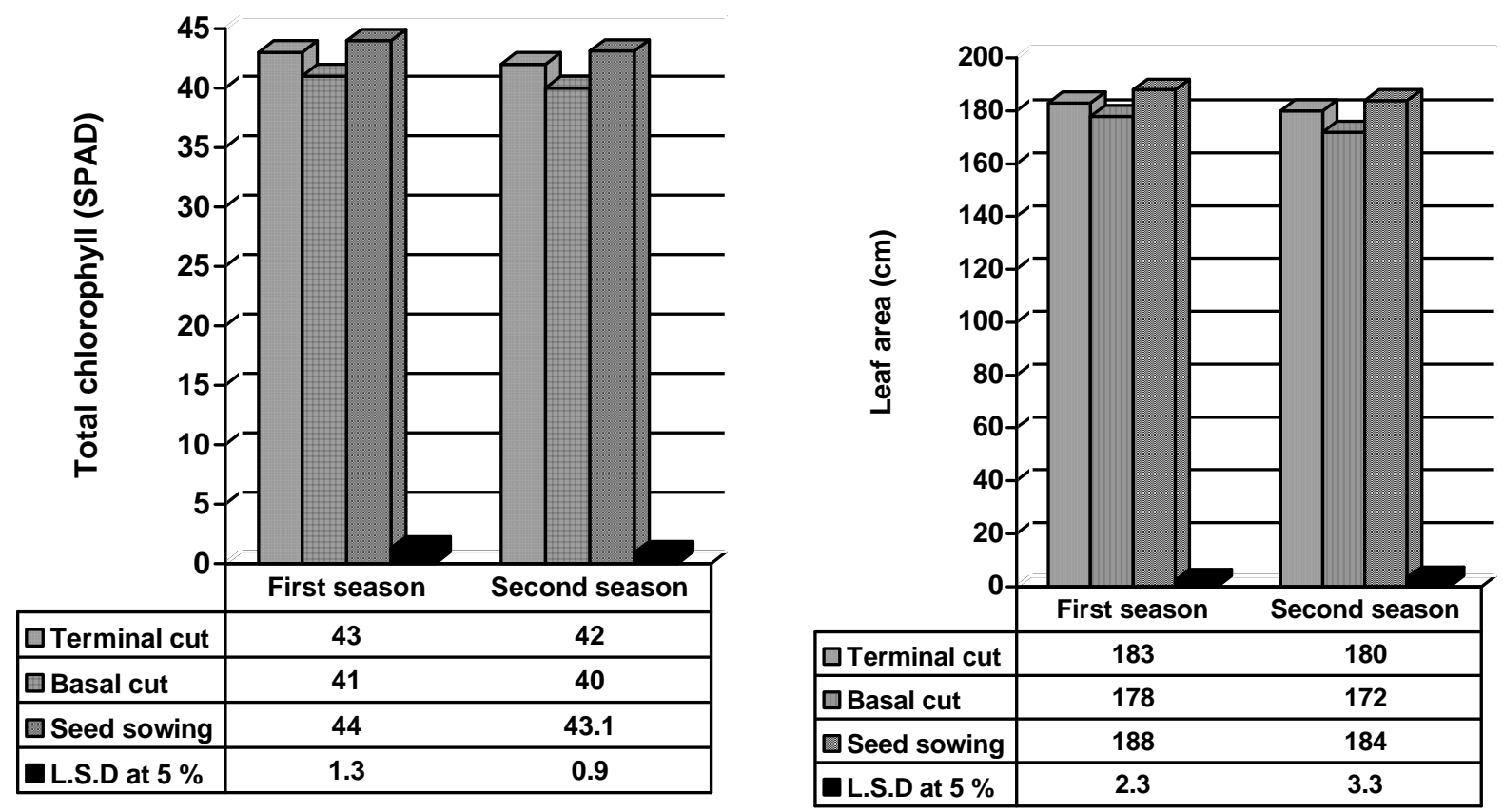

Fig. 3. Comparison between seed sowing and cutting culture on total chlorophyll and leaf area after transplanting under the greenhouse.
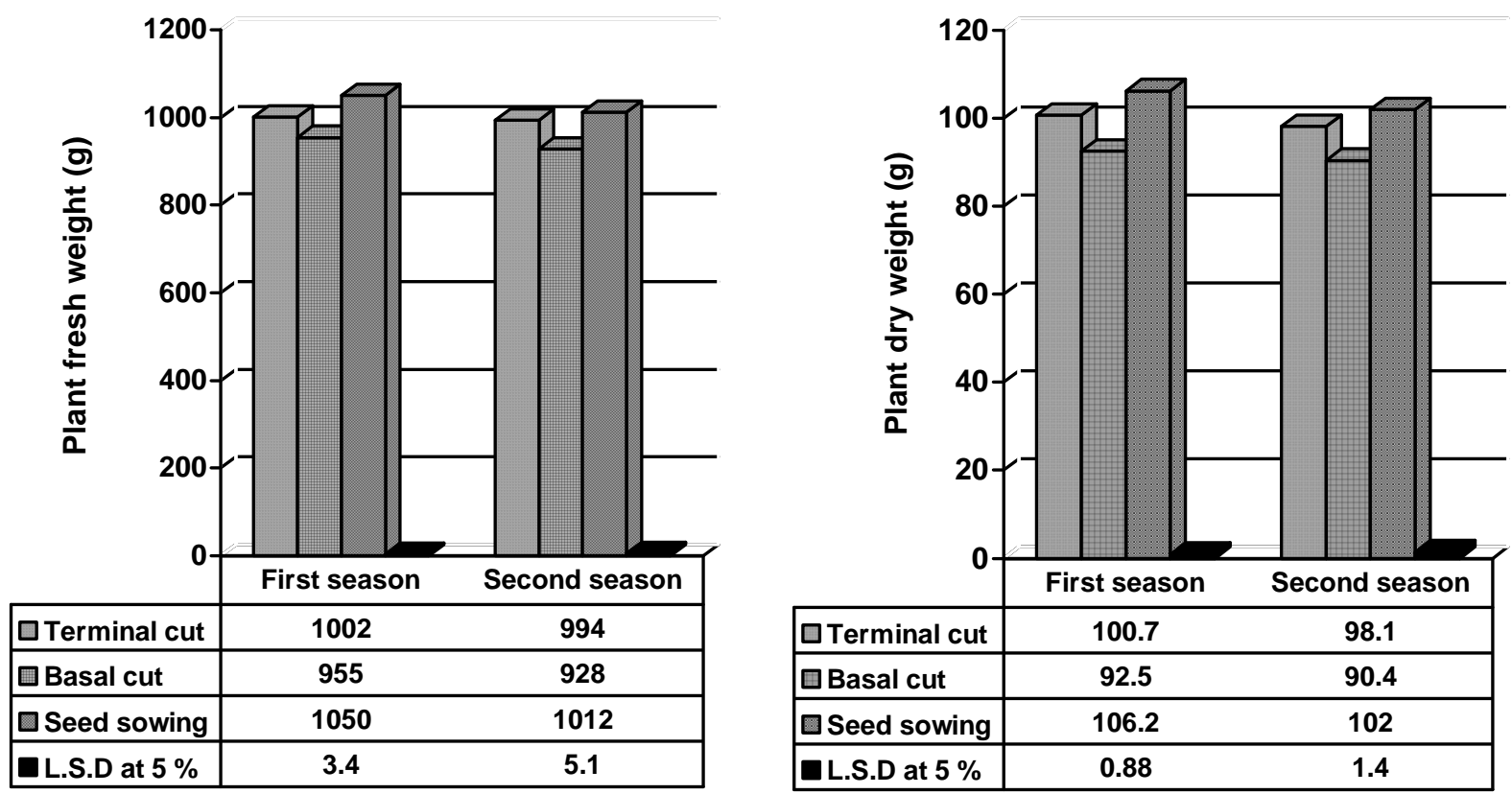

Fig. 4. Comparison between seed sowing and cutting culture on fresh and dry weight of plants after transplanting under the greenhouse. 


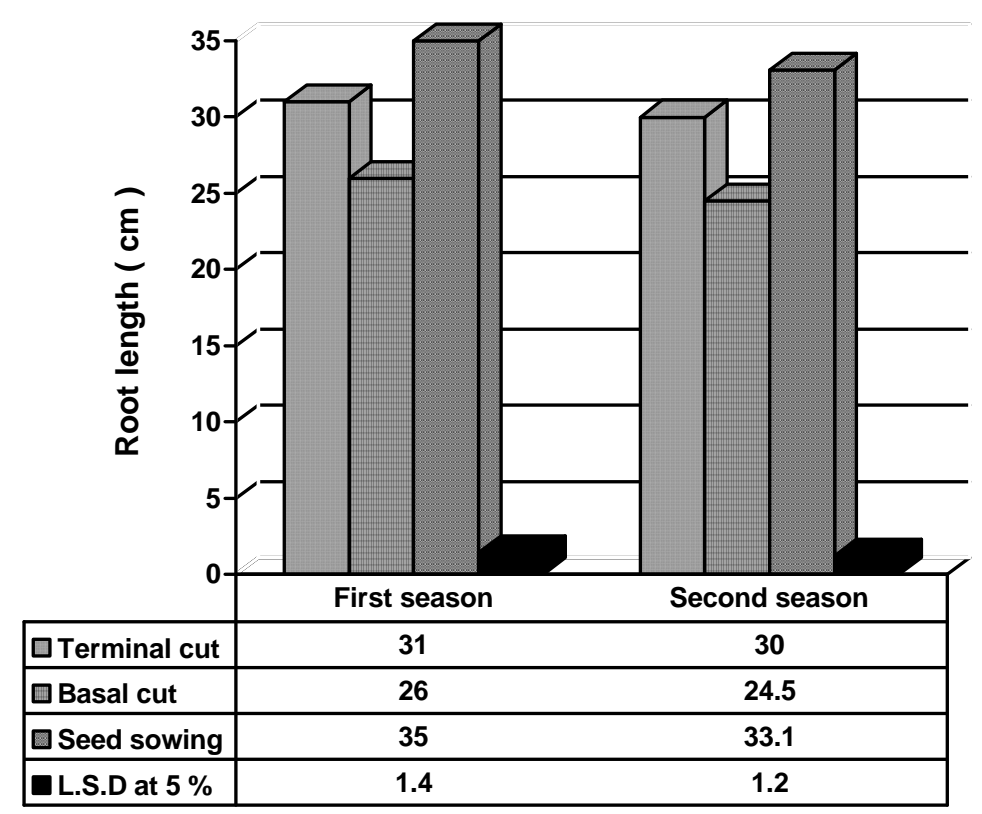

Fig. 5. Comparison between seed sowing and cutting culture on root length after transplanting under the greenhouse.

\section{B-Yield and fruit characters}

Data presented in Figs ( 6 and 7) exhibited that the conventional plant cultivation was significantly superior than cutting propagation in producing higher fruit yield expressed as early and total yield per plant, number of fruits per plant as well as average fruit weight, in the two seasons. These results may be due to that the traditional plant propagation gave plants with higher plants length, leaf area, root length, total chlorophyll, fresh and dry weight compared to cutting methods. This in turn may reflect high content of carbohydrates which gave simulative effect for more cell division and enlargement inducing more vegetative vigorous plants, this reflect producing more total yield than those of plants planted by cuttings (Robinson et. al., 1993, El-Zeiny, 2002). 

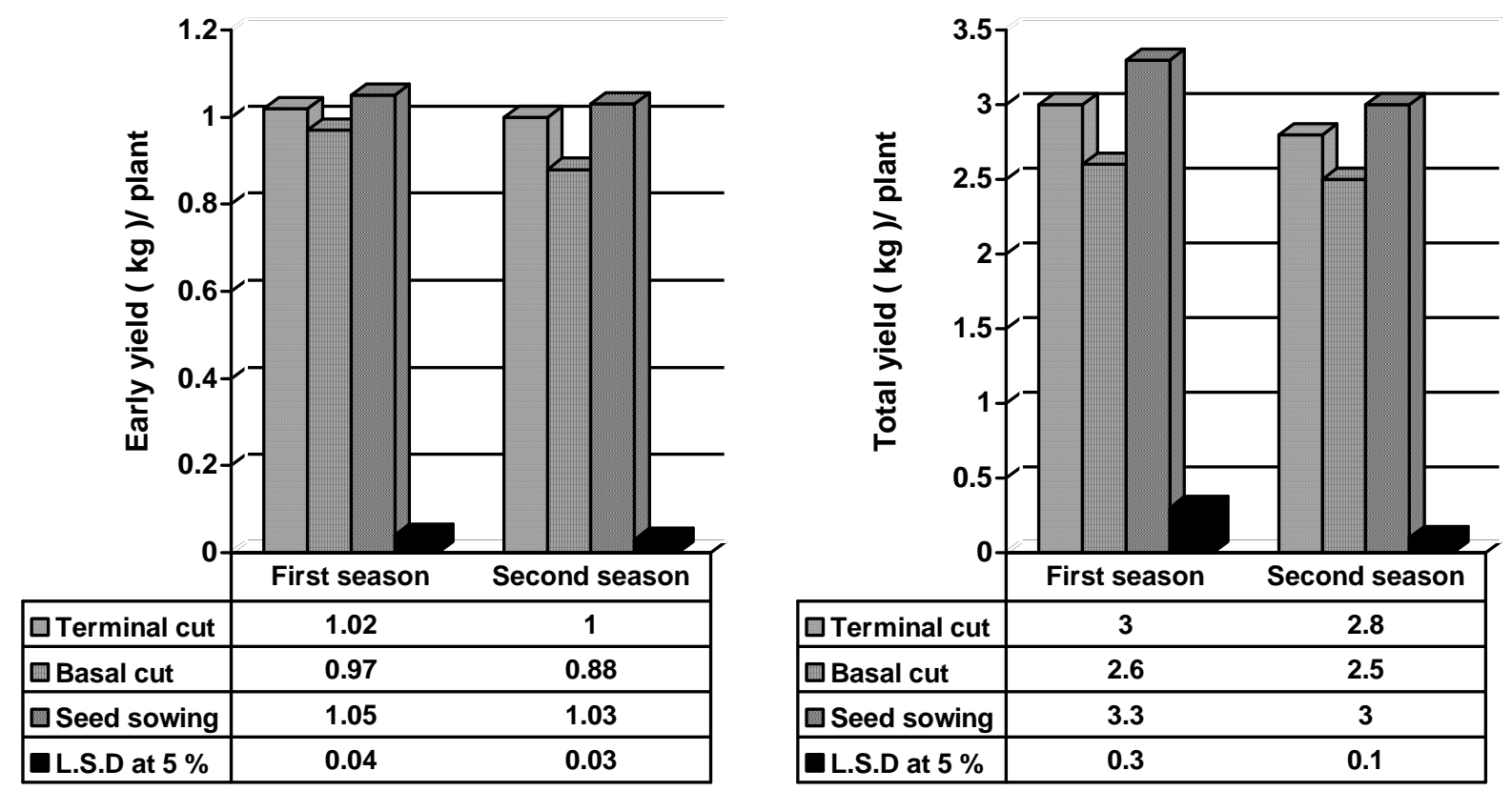

Fig. 6. Comparison between seed sowing and cuttings culture on early and total yield of cucumber hybrid.
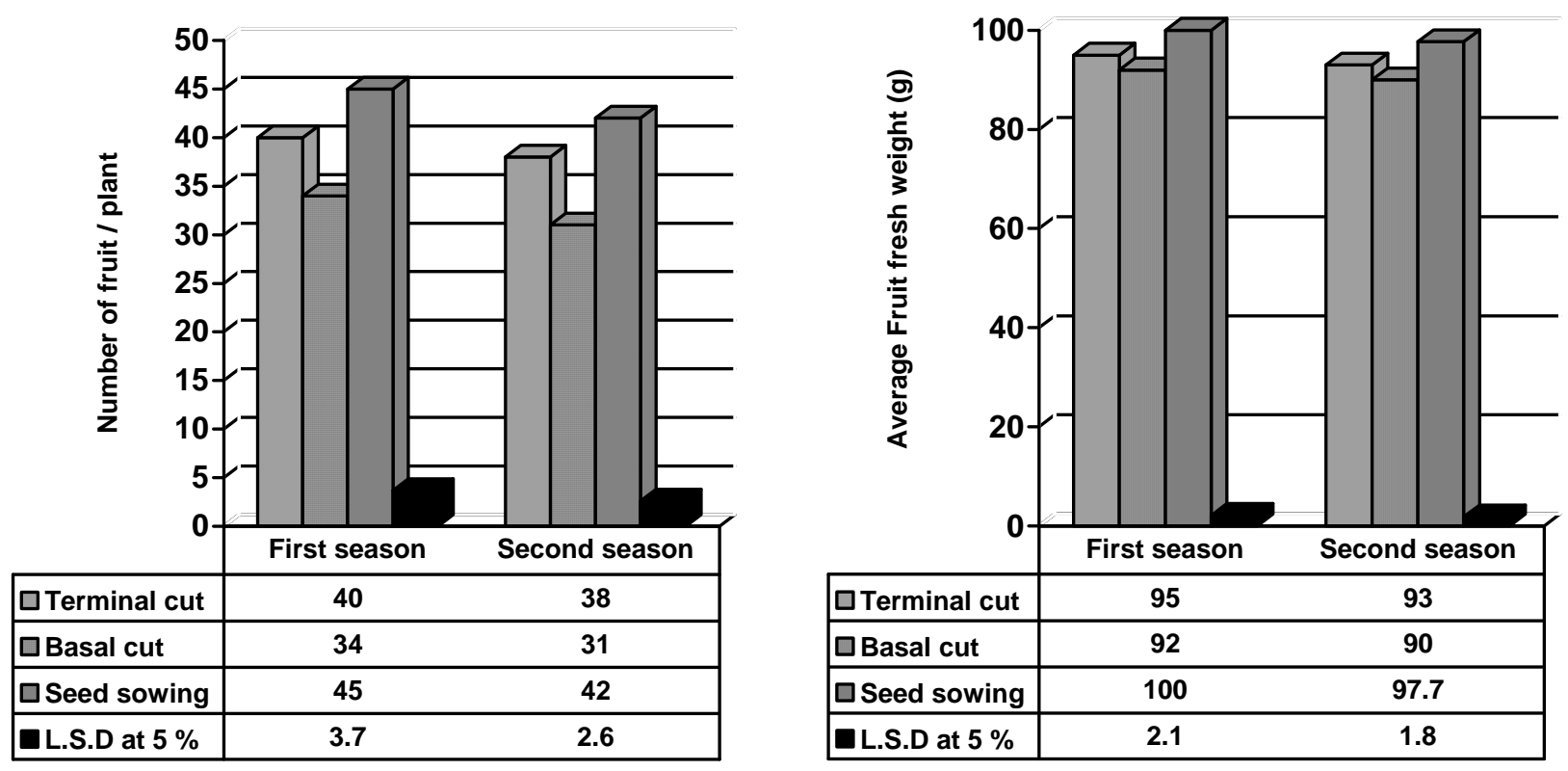

Fig. 7. Comparison between seed sowing and cuttings culture on number of fruit and fruit fresh weight of cucumber hybrid. 


\section{C: Economical evaluation}

Comparing study was done to evaluate the price of seedlings obtained by traditional nursery method and cutting methods. The differences were calculated in terms of Egyptian pounds according to the price of the market. These values were presented in Table (2) which calculate in details the total costs of 1200 seeds needed to be planted in one plastic house and those seedlings derived from cutting culture (terminal and basal) .

Data in Tables ( 1 and 2 ) indicate that the total cost price of conventional plants reached 937.00 Egyptian pounds meanwhile it was 107.00 for cutting culture methods .On the other side average of total yield produced from seed sowing was $3840 \mathrm{~kg}$ compared with 3480 and 3120 obtained from terminal and basal cutting, respectively. The total income profitable for conventional plants reached 4823 L.E and amounted to 5113 and 4573 L.E for terminal and basal cutting methods, respectively, as presented in Table (2).

Table 1. Economical analysis of total cost price of seedlings obtained by conventional method and cutting propagation.

\begin{tabular}{|c|c|c|c|c|}
\hline \multirow[b]{2}{*}{ Items } & \multirow[b]{2}{*}{$\begin{array}{l}\text { Price per unit } \\
\text { (Egyptian } \\
\text { pound) }\end{array}$} & \multicolumn{3}{|c|}{ Total cost price (Egyptian pound) } \\
\hline & & $\begin{array}{l}\text { Conventional } \\
\text { plants }\end{array}$ & $\begin{array}{l}\text { Terminal } \\
\text { Cuttings }\end{array}$ & $\begin{array}{l}\text { Basal } \\
\text { Cuttings }\end{array}$ \\
\hline Seed stock & & 1200 & 00 & 00 \\
\hline Price of seed stock & 0.70 & 840 & 0.00 & 0.00 \\
\hline $\begin{array}{c}\text { Price of netted pots for } 1200 \\
\text { seedlings }\end{array}$ & 0.06 & 72 & 72 & 72 \\
\hline $\begin{array}{l}\text { Price of substrates / seedlings } \\
\qquad(50 \mathrm{~kg})\end{array}$ & 0.50 & 25 & 25 & 25 \\
\hline Price of chemical solution (IBA) & 10 & 0.00 & 10 & 10 \\
\hline \multicolumn{2}{|c|}{ Total cost price of seedlings production } & 937 & 107 & 107 \\
\hline
\end{tabular}

Table 2. Economical analysis of total profit (net income) obtained from seedlings produced by conventional method and cutting propagation.

\begin{tabular}{|c|c|c|c|}
\hline Items & $\begin{array}{c}\text { Conventional } \\
\text { plants }\end{array}$ & $\begin{array}{c}\text { Terminal } \\
\text { cuttings }\end{array}$ & Basal \\
cuttings \\
\hline
\end{tabular}




\begin{tabular}{|l|c|c|c|}
\hline Total seedlings production & 1200 & 1200 & 1200 \\
\hline Total cost price of seedling production (pound) & 937 & 107 & 107 \\
\hline $\begin{array}{l}\text { Average total yield in two } \\
\text { season/plant (kg) }\end{array}$ & 3.20 & 2.90 & 2.60 \\
\hline $\begin{array}{l}\text { Average total yield in two season /1200 plant } \\
(\mathrm{kg})\end{array}$ & 3840 & 3480 & 3120 \\
\hline Price of sold one Kg & 1.50 & 1.50 & 1.50 \\
\hline Profit for sold all yield & 5760 & 5220 & 4680 \\
\hline Total net income & 4823 & 5113 & 4573 \\
\hline
\end{tabular}

\section{GENERAL CONCLUSION}

It can concluded that for saving more money from the costs of cucumber hybrid seeds, we can re-use the waste terminal cuttings taken from pruning side shoots of cucumber hybrids grown under greenhouse condition. We can say that the asexual propagation of cucumber hybrid (Hesham) by terminal cutting method may be considered the best way to stop the increasing price of hybrid seeds year after year and also a great source of cucumber seedlings for planting season after season .

\section{REFERENCES}

1. Ali, M. 1980. Studies on carobs propagation by cuttings. Ph.D.Thesis Facult. of Agriculture. Ain Shams Univ. Cairo.

2. Battern, D. J. and P. B. Goodwin. 1978. Phytohormones and the induction of adventitious roots. Plant Physial; 29: 355 - 362.

3. El- Abd, M.T.G. 1997. Vegetative propagation of cucumber hybrid. Egypt J. Hort.24 (1): $59-66$.

4. El-Zeiny O. A. H. 2002. Using tissue culture as a tool for increasing the productivity of seedlings and total yield of some pepper hybrids. Arab Univ.J. Agric., Ain Shams Univ.Cairo. 10:273 -285.

5. Hess. D. 1981. Plant physiology, molecular, biochemical and physiological fundamental of metabolism and development. Narosa Publishing. House 2/35, Ansari Road New Delhi, 110002.

6. Ikram, S. A. 1983. Comparative studies on easy to root and hard to root cuutting of olive. Ph.D.Thesis Facult. of Agriculture. Ain Shams Univ. Cairo. 
7. Mullins, M. G. 1972. Auxin and ethylene in adventitious root formation in (Phaseolus aureus). "Plant growth substances". Spring- Verlag Berlin, Heidelberg, New York, pp. 526 - 533.

8. Robinson, J. C., C. Fraser and K. Eckestein. 1993. A field comparison of conventional suckers with tissue culture banana planting material over three crop cycle. J.Hort.Sci.,68: 831-836.

9. Seeley, S.D. 1990. Hormonal transduction of enviromental stress. Hort. Sci., 25(11): $1369-1376$.

10. Snedicor, G. W. and W. G. Cochran. 1980. Statistical Methods.Sixth Edition, IowaState Univ. Press, Amer., Iowa. USA..

دراسة مقارنة على زراعة هجن الخيار باستخدام العقل والطرق التقليدية

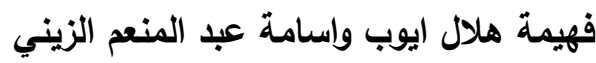




$$
\text { معهُ بحوث البساتين - اقسام بحوث الخضر - دقى - جيزة - مصر }
$$

يهدف هذا البحث الى إعادة استخدام الأجزاء المتحصل عليها من الأفرع الناتجـة من جراء عملية السرطنة لتقليل تكاليف انتاجية هجن الخيار النامية تحت الصوب.

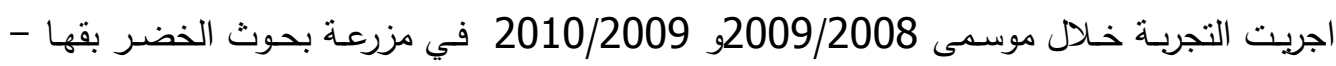
محافظة القليوبية على هجين خيار هشام باستخدام نوعين من العقل وهي عقلة طرفية وعقلة قاعدية

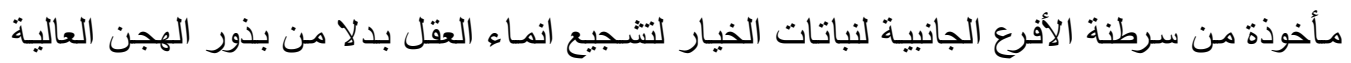
الثمن قد وجد ان استخدام العقلة الطرفية كان افضل من العقلة القاعدية في كل من نسبة نجاح العقلة وطول الجذور والوزن الطازج والجاف للشتلة .

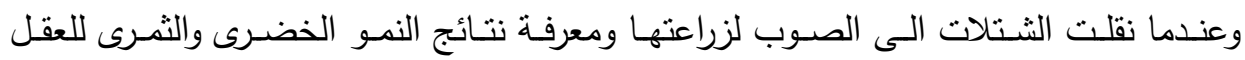

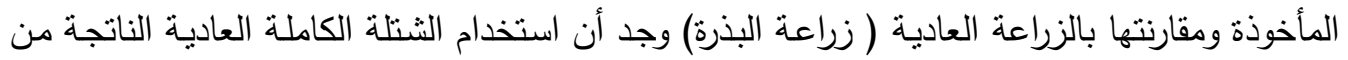

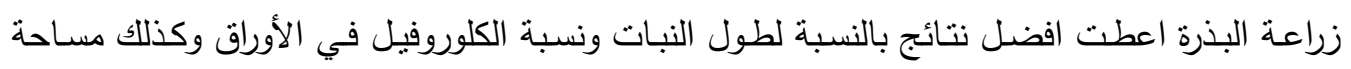

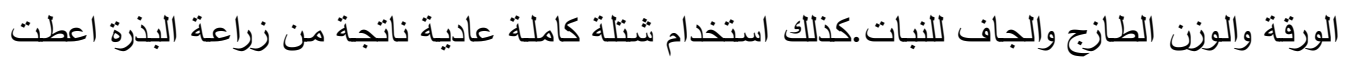
افضل نتائج بالنسبة للمحصول المبكر والكلي مقارنة باستخدام العقل الطرفية والقاعدية. كما اجريت جدوى اقتصادية لتقدير التكلفة الكلية لاستخدام كل من الثتلات العادية والعقل . باستئل أوضحت النتائج المتحصل عليها ان استخدام العقل ادى الى تقليل التكلفة مع زيادة محدودة للعائد 